\title{
Function of Education
}

\begin{abstract}
$\mathrm{T}$ HE discussion on "Education for a Changing Society" arranged by Section L (Educational Science) of the British Association on August 19 and 22 was maintained at a high level well worthy of the crowded audiences which it attracted.

In opening the discussion, Mr. W. H. Robinson dealt with the senior school, which he described as pre-eminently the school of the people, the vast majority of the electorate. Most of the pupils of the senior school would receive no further organized education but would be educated by their environment, both physical and mental. He suggested that the essential function of school in a changing society is to teach pupils the art of self-education to be continued through life, and to give them a conviction that education is not a thing of school alone. The school should provide a connecting thread running through the educative influence of the cinema, radio, picture paper and environment generally. Accordingly, the school must be related at all points to the community and, as the Hadow Committee insisted, the curriculum must be thought of in terms of experience and activity rather than of knowledge to be acquired and facts to be stored.
\end{abstract}

The years from eleven to fifteen, Mr. Robinson urged, should be used to consolidate the training already given, by taking into full account the psychology of the adolescent of this age. By becoming leaders of the school community, by experience of the organization of school activities, by discussion and attempts at agreement, they would learn by experience the basic facts on which our democracy is based and the lines along which it must develop. In this way they would learn the necessity for patience, persuasion and compromise, respect for the opinions and form of action of others, and that toleration is better than coercion. This learning through experience, Mr. Robinson considers, is more important than lessons, and the great need appears to be for the development of a technique for developing the active co-operation of the pupil in the work of self-education for life.

The second paper, by Miss Ruth Dawson, also dealt with the senior school, and emphasized the importance, in view of the background and environment of the modern child, of giving an education designed not to accumulate facts but to train the mind to make right judgments. Once again reference was made to the aims set forth in the Hadow Report and the importance of all subjects in the curriculum contributing to the formation and strengthening of character, the training of tastes which would fill and dignify leisure, and to the awakening and guiding of intelligence. Miss Dawson referred in illustration to the use and opportunities of physical training, domestic science, arts and crafts, drama, etc.

The part of the secondary school was discussed in papers by Dr. P. T. Freeman and Miss Muriel Davies which presented two opposite, but not necessarily opposed, points of view and were afterwards rather severely criticized by Mr. H. G. Wells. Dr. Freeman stressed the importance of discipline and urged that it is necessary not only to arouse interest but also to demand effort. $\mathrm{He}$ deplored the recent agitation against homework and said that, in spite of the independence of the modern child, there is a lack of vitality and willingness to tackle difficulties. Dr. Freeman urged the value of Latin and Euclid in training, particularly as teaching children not to accept statements without adequate evidence. He advocated a three-year course in biology as a means of conveying information about sex and, while supporting an extension of the teaching of civics and economics, considers that over-emphasis on apparatus in physical training is dangerous. Although he was severely taken to task by Mr. Wells for his advocacy of Officers' Training Corps, his opinion of the value of such training in developing not only discipline but also self-reliance will certainly find strong support.

Miss Muriel Davies, on the other hand, devoted much of her time to an analysis of social conditions and of the way in which inequalities are perpetuated in our present educational system. She pleaded eloquently for a unification of our educational system particularly in the ranks of the teacher, the abolition of distinctions in salary scales between elementary and secondary school teachers, and the evolution of a system of education for social progress rather than for individual advancement. Miss Davies's address contained many almost startling suggestions, designed to promote co-operation rather than competition and to break down class distinctions, such as the abolition of formal hours and holidays, the education of rich and poor together, the requiring of all teachers to spend some time in elementary schools; but the vision and idealism of the address warmly commended it to the large audience, not the less because it was constructive and forward looking. She deprecated the use of prizes and marks for stimulating effort, but although she advocated more freedom of choice for children in their actual work both in and out of the school, her insistence on the encouragement of the community spirit and sugges. tion for a group system in place of the house or house prefect system should have safeguarded her from Mr. Wells's stricture.

Continuing the discussion on August 22, Mr. J. Paley Yorke dealt with the functions and work of the junior technical school, the importance of which is enhanced by the decay of the apprenticeship system. He laid particular stress upon the importance of the staff possessing adequate industrial experience in view of its bearing on the content and presentation of the training. Dr. W. A. Richardson discussed the place of the technical college. Pointing out the disparity between our knowledge of the material world and our knowledge of mind and social relations, he stressed the need for research in the latter field. Social conditions profoundly affect the work of technical colleges, as of all education and educational ideals, and Dr. Richardson instanced the danger that the rearmament programme will have untoward effects in the educational field. There are wide differences between technical colleges, and the voluntary system has a serious defect in the leakage of students, many of whom do not stay the course. Moreover, difficulties also arise because often the students attend primarily for training in occupations 
other than that which they are following at the moment. There is less leakage of students entering technical colleges from the junior technical schools than of students of any other type.

Dr. Richardson considers that the raising of the school age would assist the work of the technical colleges; but if education is to be effective, it must be compulsory until the age of mental maturity-at least until eighteen. The idea of the local college, which is a community of students whose main purpose in attending is educational, and not social, but for whom the authorities must provide facilities for social and physical development in the fullest sense, is gaining ground. Such colleges would necessarily continue to have a vocational and industrial bias, endeavouring to develop skill as well as to impart technical knowledge and training in administration both in the industrial and the civic sphere.

Mr. F. Pick, whose paper drew the warm approval of Mr. H. G. Wells, criticized education for failing to give to the new subjects of an industrial civilization the breadth and quality which is given to the older subjects bred in the classic ages. He argued for a new type of university of the eye and hand as distinct from that of the voice and the pen. It should be possible to illuminate the accumulated knowledge of trade and industry with a wisdom and understanding which would make it a suitable medium for a liberal education. The trained and broadened mind should be applied to the building up out of the mass of knowledge which they embody, human sciences to rank with ethics, politics, economics and sociology.

Prof. Winifred Cullis followed with a final paper in which she dealt with some questions confronting the universities in the changing world. With regard to the aims of university education, there is a great consensus of opinion as expressed both by staff and by students, and the stress is laid on training for living rather than for a livelihood. She referred to a number of particular problems raised in recent reports, such as the question whether a specialist training for particular careers is the best for developing leaders of informed public opinion, for men and women who are to be politicians, administrators, journalists or teachers. Again, there is the question whether post-graduate teaching should be concentrated in particular universities, in which connexion
Prof. Cullis referred to the backward position of postgraduate education in medicine in Great Britain compared with that in other countries. The extension of the system of individual tutorship to all universities, and increased facilities for short-term ex. changes of staff between different universities both in Great Britain and abroad, and the provision of increasing numbers of residential halls are all matters requiring consideration.

Prof. Cullis laid particular stress on the importance of greater attention to the question of the health of students, and strongly supported the demand for physical education and health services at the universities. She is in favour of compulsory medical examinations at regular intervals, pointing out that it is often the students who can least afford medical advice who most need it and that such examination could often prevent serious illness developing later. She outlined a number of health insurance schemes, both optional and compulsory, which have been developed for students in Great Britain or abroad, and finally stressed the importance of including training for the responsibilities of citizenship.

Lord Stamp, who opened the discussion, was decidedly more critical than Mr. H. G. Wells of Mr. Pick's paper. He pointed out that we cannot say what changes in education are desirable until we have decided what is the right direction for such changes to take; what is the optimum speed at which they should be made; how they can be made with the least waste; and what should be the correct agencies for bringing them about. Some account must now be taken of the changes in the rate of growth of the population and of its possible physical obsolescence, and Lord Stamp referred particularly to the importance of considering training which would give the right outlook and background to those occupying the intermediate executive positions, since they have so much influence on the selection from the younger men and women of those who in later life will occupy the positions of highest responsibility. He strongly supported the idea of refresher classes and post-graduate courses for those already occupying business or professional posts. Sir Richard Livingstone criticized the teaching of history and philosophy at an age too early for adequate appreciation, and expressed his regret that adult education had not been included in the discussion.

\section{New Science Buildings at Shrewsbury School}

\begin{abstract}
$\mathrm{O}^{\mathrm{N}}$ September 24, Sir William Bragg, president of the Royal Society, opened the new science building at Shrewsbury School. Charles Darwin was at the School from 1818 until 1825, and the building, hitherto used for science teaching, erected in 1903, was named after him. It has been considerably re-modelled and improved for chemistry teaching under the present building programme. The new building was dedicated "in thankful commemoration of the life and work of Charles Darwin".

The new science building comprises two floors, the ground floor being devoted to physics, and the first floor to biology. The latter floor is some two thirds the area of the ground floor and is masked on three faces by roof slopes, it being the desire that this new building should conform to the general style of
\end{abstract}

adjacent buildings, which are mostly of one story. The construction is of brick, with hollow tile fireresisting floors, and tiled roofs with asphalt flats between. All rooms are fully plastered, and floors generally are of teak blocks. Heating is by lowpressure hot water radiators.

The ground floor (physies) has two large elementary laboratories, each for 26 students, with a common preparation - store room, an advaneed laboratory for 16 students, two lecture rooms to seat 26 each, a large store room and a photographic dark room. Both elementary laboratories are alike in fitments; long fixed double-sided table type benches, having gas and electric services, occupy the middle of the room. Fnclosed balance cases in groups are disposed around the walls, and two large sinks are 